\title{
ANALISIS KONFLIK BATIN TOKOH UTAMA DALAM NOVEL IBU, AKU MENCINTAIMU KARYA AGNES DAVONAR
}

\author{
RIA PERMATASARI \\ riapermatasari010@gmail.com \\ Universitas Muhammadiyah Sukabumi
}

\begin{abstract}
Abstrak Sastra merupakan suatu pengungkapan ekspresi dari manusia berdasarkan hasil pemikiran, pengalaman, ide, ataupun gagasan yang dituangkan ke dalam bentuk karya sastra dengan medianya berupa bahasa. Penelitian ini bertujuan untuk mendeskripsikan konflik batin tokoh utama berupa bentuk-bentuk serta faktor penyebab konflik batin tokoh utama pada novel Ibu, Aku Mencintaimu karya Agnes Davonar. Jenis penelitian ini merupakan penelitian kualitatif dengan menggunakan metode deskriptif. Sumber data yang digunakan dalam penelitian ini adalah novel Ibu, Aku Mencintaimu karya Agnes Davonar yang berjumlah 190 halaman. Teknik pengumpulan data yang digunakan yaitu teknik kepustakaan. Peneliti membaca dan memahami teks novel lalu mencatat data-data yang diperlukan dalam analisis dan menguraikan data tersebut sebagai hasil penelitian. Hasil penelitian ini menunjukan bahwa terdapat sepuluh bentuk konflik batin yang terdapat pada novel $I b u, A k u$ Mencintaimu karya Agnes Davonar. Bentuk konflik batin yang terdapat pada novel Ibu, Aku Mencintaimu karya Agnes Davonar yaitu depresi, cemas, obsesi,marah, rasa salah, jengkel, bimbang, sakit hati, tidak puas, dan ketergantungan. Faktor penyebab yang terdapat pada novel Ibu, Aku Mencintaimu karya Agnes Davonar yaitu persepsi diri dan Cognitive Map, early deprivation, dan struktur keluarga yang patogenik.
\end{abstract}

Kata kunci: Konflik batin, tokoh utama, novel

Abstract. Literature is expression of human based on thoughts, experiences, ideas, or ideas expressed in a literally work with a medium of language. This study aims to describe the main character's inner conflict in the form of forms and factors that cause the main character's inner conflict in the novel Mom, I Love You by Agnes Davonar. This type of research is a qualitative research using descriptive method. The data source used in this research is the novel Mom, I Love you by Agnes Davonar, which has 190 pages. The data collection technique used is library technique. The researcher reads and understands the text of the novel and then records the data needed in the analysis and describes the data as a result of the research. The results of this study indicate that there are ten forms of inner conflict contained in the novel Mom, I Love You by Agnes Davonar. The forms of inner conflict found in the novel Mom, I Love You by Agnes Davonar are depression, anxiety, obsession, mad, guilt, annoyance, indecision, hurt, dissatisfaction, and dependence. The causative factors found in the novel Mom, I Love You by Agnes Davonar are self-perception, early deprivation, and a pathogenic family structure.

Keywords: Inner conflict, main character, novel

\section{PENDAHULUAN}

Sastra merupakan suatu pengungkapan ekspresi dari manusia berdasarkan hasil pemikiran, pengalaman, ide, ataupun gagasan yang dituangkan ke dalam bentuk karya sastra dengan medianya berupa bahasa. Sastra merupakan suatu karya fiksi hasil imajinasi pengarang. Meskipun disebut sebagai karya fiksi, tetapi cerita yang diambil bersumber dari fenomena yang terjadi di kehidupan sekitarnya. Suatu karya sastra akan tercipta apabila seorang pengarang memiliki daya kreativitas dan inspirasi sehingga dapat mengembangkan karya sastra yang akan dibuat baik itu ke dalam bentuk prosa, puisi, maupun drama.

Salah satu karya sastra berbentuk prosa adalah novel. Novel merupakan salah satu karya sastra berbentuk prosa 


\section{RIA PERMATASARI \\ ANALISIS KONFLIK BATIN TOKOH UTAMA DALAM NOVEL IBU, AKU MENCINTAIMU KARYA AGNES DAVONAR}

yang ceritanya panjang dibandingkan dengan cerpen sehingga dapat mengemukakan sesuatu secara lebih rinci dengan melibatkan berbagai permasalahan yang kompleks, sebagaimana pendapat yang dikemukakan oleh Nurgiyantoro (2018 :13) yang menyatakan bahwa novel mengemukakan sesuatu secara lebih bebas, sesuatu yang disajikan lebih detail, serta terdapat berbagai permasalahan atau konflik yang rumit. Hal ini menunjukan bahwa novel mampu menyampaikan permasalahan yang kompleks secara penuh.

Tujuan peneliti atau pemerhati pada hakikatnya ketika membaca suatu karya sastra yaitu untuk menikmati atau mengapresiasi karya sastra tersebut, sehingga mereka bergelut dengan tokoh penokohan yang menampilkan berbagai watak dan perilaku yang memiliki kaitan dengan kejiwaan dan pengalaman psikologis atau konflik batin yang dialami oleh manusia dalam kehidupan nyata. Hal ini sejalan dengan pendapat yang dikemukakan oleh Minderop (2018: 1) bahwa para tokoh yang diciptakan oleh pengarang menampilkan berbagai watak dan perilaku yang memiliki kaitan dengan kejiwaan dan pengalaman psikologis atau konflikkonflik sebagaimana yang dialami oleh manusia di dalam kehidupan nyata. Masalah-masalah kejiwaan tersebut dapat disebut sebagai konflik-konflik psikologis atau konflik batin. Salah satu pengarang yang dalam karyanya banyak membahas tentang konflik batin yaitu Agnes Davonar dalam novelnya yaitu Ibu, Aku Mencintaimu.

Novel Ibu, Aku Mencintaimu menceritakan tentang konflik batin yang dialami oleh tokoh utama yaitu Angel. Novel tersebut merupakan kisah atau cerita sedih yang didalamnya terdapat konflik-konflik, terutama konflik batin yang dialami oleh tokoh utama yaitu Angel. Konflik batin yang dialami oleh tokoh utama yaitu kemarahan, kebencian, kekecewaan, terhadap sang ibu yang harus membuatnya mengalami penderitaan yang akhirnya membuatnya mengalami konflik batin karena permasalahan dengan ibunya.

Kelebihan yang terdapat pada novel Ibu, Aku Mencintaimu karya Agnes Davonar yaitu di dalamnya terdapat berbagai macam konflik batin yang dihadapi oleh para tokoh sehingga pembaca dapat mengambil pelajaran hidup karena di dalamnya terdapat pesan moral tentang kehidupan. Selain itu, novel Ibu, Aku Mencintaimu karya Agnes Davonar merupakan novel yang mendapatkan penghargaan sebagai novel The Best Sad Onlie Story (2014) serta merupakan salah satu novel Best Seller. Berdasarkan hal tersebut, peneliti tertarik untuk mengkaji novel $\mathrm{Ibu}, A k u$ Mencintaimu karya Agnes Davonar (Davonar, 2016).

Berdasarkan hal-hal yang diuraikan pada paragraf-paragraf sebelumnya, peneliti tertarik untuk melakukan penelitian terhadap novel Ibu, Aku Mencintaimu karya Agnes Davonar. Penelitian ini berjudul Konflik Batin Tokoh Utama pada Novel Ibu, Aku Mencintaimu karya Agnes Davonar. Penelitian ini akan berfokus pada konflik batin yang dialami oleh tokoh utama yaitu berupa bentuk-bentuk konflik batin serta faktor penyebab konflik batin pada tokohutama

\section{METODE PENELITIAN}

Metode yang digunakan dalam penelitian ini adalah metode penelitian kualitatif, dengan cara deskriptif analisis. Metode deskriptif kualitatif analisis yaitu penelitian yang dilakukan dengan cara mendeskripsikan fakta-fakta yang ada, kemudian dilakukan analisis terhadap data-data tersebut, dan interpretasi data. Data dalam penelitian ini adalah teks novel. Penelitian ini menggunakan pendekatan deskriptif karena sumber data yang diteliti langsung berupa teks novel karya Agnes Davonar yang berjumlah 190 halaman. Instrumen kunci untuk menganalisis data adalah peneliti sendiri.

Siyoto \& Sodik, (2015) menyatakan bahwa metode penelitian kualitatif merupakan metode penelitian yang lebih menekankan pada aspek pemahaman secara mendalam terhadap suatu masalah daripada melihat permasalahan untuk penelitian generalisasi. Metode penelitian kualitatif lebih suka menggunakan teknik analisis mendalam. Yaitu mengkaji masalah secara kasus perkasus karena metode penelitian kualitatif yakin bahwa sifat suatu masalah akan berbeda dengan masalah lainnya. 


\section{RIA PERMATASARI \\ ANALISIS KONFLIK BATIN TOKOH UTAMA DALAM NOVEL IBU, AKU MENCINTAIMU KARYA AGNES DAVONAR}

Teknik pengumpulan data yang digunakan oleh peneliti yaitu sebagai berikut :

Membaca dan Memahami Novel

Peneliti membaca novel $I b u, A k u$ Mencintaimu karya Agnes Davonar tersebut dan memahami struktur, serta konflik batin yang dialami oleh tokoh utama yang terdapat pada novel $I b u, A k u$ Mencintaimu karya Agnes Davonar.

Mencatat Data-Data yang Diperlukan dalamAnalisis

Peneliti mencatat data-data yang diperlukan untuk menganalisis novel Ibu, Aku Mencintaimu karya Agnes Davonar. Data yang diperlukan oleh peneliti yaitu menganalisis struktur novel yaitu tokoh penokohan, bentuk konflik batin yang dialami tokoh utama serta penyebab konflik batin yang dialami oleh tokohutama.

Menguraikan Data

Setelah peneliti melakukan pencatatan, selanjutnya peneliti menguraikan hasil data tersebut

\section{HASIL DAN PEMBAHASAN}

Hasil penelitian ini terdiri dari dua bagian, yaitu

1) bentuk-bentuk konflik batin pada tokoh utama, 2) faktor penyebab konflik batin pada tokoh utama.

Bentuk-Bentuk Konflik Batin pada TokohUtama

Pada analisis data yang dilakukan oleh peneliti terdapat beberapa macam bentuk konflik batin yang terdapat pada novel Ibu, Aku Mencintaimu karya Agnes Davonar, diantaranya (1) bentuk konflik batin dalam novel $I b u, A k u$ Mencintamu karya Agnes Davonar meliputi (a) depresi, depresi merupakan puncak kesedihan seseorang yang begitu mendalam. Depresi ditandai dengan perasaan tidak beruntung, kehilangan, dan ketidak berdayaan. (b) obsesi, obsesi Seseorang dikatakan obsesi apabila dia terus menerus mengalami suatu perasaan atau dihantui oleh pikiran-pikiran yang terus menerus timbul menguasai alam kesadarannya. (c) cemas, cemas merupakan salah satu bentuk konflik batin yang terjadi pada diri seseorang. Gejala seseorang mengalami cemas yaitu bila dia merasa kuatir dan gamang terhadap sesuatu hal yang tidak menyenangkan. (d) rasa salah ditandai oleh munculnya perasaan menyesal atau malu karena suatu perilaku yang tercela.

(e) marah, seseorang menjadi marah apabila dia merasa tersinggung, sakit hati, atau jengkel tehadap perilaku orang lain. (f) jengkel, perasaan jengkel muncul ketika seseorang merasa tersinggung oleh perilaku orang lan sehingga menimbulkan kejengkelan karena dirinya diganggu, diusik, atau bahkan tidak dihiraukan. (g) bimbang, gejala seseorang mengalami kebimbangan yaitu apabila orang tersebut ragu atau goyah untuk melakukan suatu pilihan. (h) sakit hati, rasa sakit hati timbul ketika seseorang mendapatkan perlakuan yang kurang menyenangkan dari orang lain. Perlakuan yang kurang menyenangkan tersebut dapat berupa penghinaan, bersikap kasar, sindiran, memandang rendah, mengejek, atau tidak menghargai dirinya. (i) tidak puas, gejala seseorang tidak puas yaitu ketika tidak memperoleh atau tidak mencapai sesuatu yang diinginkannya.(j) ada 2 bentuk ketergantungan yaitu ketegantungan yang percaya dan ketergantungan yang parasit. Ketegantungan yang percaya yaitu apabila ketergantungan timbul terhadap keyakinan atau kepercayaan terhadap sesuatu atau seseorang. Sedangkan ketegantungan parasit yaitu ketergantungan yang timbul berdasarkan suatu kekurang percayaan terhadap diri, tidak mampu, dan lemah.

Depresi

Berikut ini adalah kutipan yang menunjukan adanya bentuk konflik batin yang terjadi pada tokoh utama berupa depresi yaitu sebagai berikut :

"sang pembawa berita mengatakan bahwa ayah adalah satu-satunya korban meninggal dalam kecelakaan itu. Aku menangis histeris, kedua sahabatku memelukku erat. Berita kematian ayah membuat aku benar-benar tak sanggup berdiri bahkan untuk berjalan sejengkalpun ketika ibu Gita mengantarkanku untuk melihat kondisi ayah setelah ia mendapatkan kabar dimana ayah berada " (Davonar, 2016 : 16).

Berdasakan kutipan di atas, dapat diketahui bahwa terdapat bentuk konflik batin yang dialami oleh tokoh utama (Angel) yaitu 


\section{RIA PERMATASARI \\ ANALISIS KONFLIK BATIN TOKOH UTAMA DALAM NOVEL IBU, AKU MENCINTAIMU KARYA AGNES DAVONAR}

depresi. Depresi yang dialami oleh tokoh utama (Angel) yaitu berupa adanya perasaan sedih yang mendalam atas kehilangan ayahnya karena kecelakaan. Bentuk konflik batin berupa depresi yang dialami oleh tokoh utama (Angel) yaitu dapat dibuktikan bahwa dalam kutipan tersebut tokoh utama (Angel) menangis histeris sewaktu mendengar berita kematian ayahnya yang meninggal dalam kecelakaan mobil. Angel merasakan kesedihan luar biasa atas kepergian ayahnya untuk selama-lamanya. Setelah mendengar berita kematian ayahnya tersebut, Angel benar-benar tidak sanggup berdiri bahkan berjalan sejengkalpun saat ibu Gita akan membawa Angel ke rumah sakit untuk menemui ayahnya.

\section{Cemas}

Berikut ini adalah kutipan yang menunjukan adanya bentuk konflik batin yang terjadi pada tokoh utama berupa depresi yaitu sebagai berikut :

"Ketiganya tersenyum dan melihat padaku. Aku tak sengaja membalas pandangan mereka dan merasa was-was ketika mereka berbicara tentang ibuku" (Davonar, 2016 : 104).

Berdasarkan kutipan di atas dapat diketahui bahwa bentuk konflik batin yang terjadi pada tokoh utama (Angel) yaitu cemas. Bentuk konflik batin berupa cemas yang dialami oleh tokoh utama (Angel) berupa cemas dapat dibuktikan bahwa dalam kutipan tersebut Angel merasa was-was jika teman- temannya tahu bahwa ibunya merupakan penjual bakmi. Jika temantemannya tahu bahwa ibunya merupakan penjual bakmi, Angel berpikir harga dirinya akan terjatuh.

Obsesi

Berikut ini adalah contoh kutipan data yang menunjukan adanya bentuk konflik batin yang terjadi pada tokoh utama berupa obsesi yaitu sebagai berikut :

“... baiklah, aku harus sekolah karena aku sadar sekolah akan membuatku tidak menjadi semiskin saat ini, dengan lulus secepatnya aku bisa mandiri dan meninggalkan kehidupan gelap seperti ini. Kini aku pun bertekad menjadi murid terbaik di sekolah sehingga mendapatkan beasiswa lanjutan ke universitas lanjutan yang kudambakan UPH karena impianku untuk sekolah menengah akhir disana gagal total" (Davonar, 2016 : 48).

Berdasakan kutipan di atas dapat diketahui bahwa bentuk konflik batin yang terjadi pada tokoh utama (Angel) yaitu bentuk konflik batin obsesi. Bentuk konflik batin berupa obsesi yang dialami oleh tokoh utama (Angel) dapat dibuktikan bahwa dalam kutipan tersebut Angel memiliki keinginan atau tekad yang kuat untuk bersekolah sehingga Angel bisa mendapatkan beasiswa ke univeristas yang diimpikannya untuk merubah kehidupannya menjadi lebih baik lagi. Setelah ayahnya meninggal, kehidupan Angel berubah menjadi miskin. Hal itu memunculkan niat yang kuat dalam diri Angel bahwa dia harus tetap bersekolah dan melanjutkan pendidikannya. Karena dengan cara tersebut, Angel dapat merubah kehidupannya yang miskin seperti saat ini.

\section{Marah}

Berikut ini adalah contoh kutipan data yang menunjukan adanya bentuk konflik batin yang terjadi pada tokoh utama berupa marah yaitu sebagai berikut :

"Ini semua gara-gara ibu... semua garagara ibu yang manja minta dijemput ayah sampai akhirnya keluarga kita jadi hancur kayak gini ... "teriakku. Ibu terkejut dengan apa yang aku katakana. Aku merasa marah dengan apa yang terjadi dan langsung pergi meninggalkan ibu" (Davonar,2015:28).

Berdasarkan kutipan di atas dapat diketahui bahwa bentuk konflik batin di atas merupakan bentuk konflik batin marah. Bentuk konflik batin marah yang dihadapi oleh tokoh utama (Angel) dapat dibuktikan bahwa dalam kutipan tersebut tokoh Angel begitu marah terhadap sikap ibunya yang manja minta dijemput sampai akhirnya ayahnya harus meninggal dalam kecelakaan. Angel menyalahkan ibunya atas kejadian yang menimpa ayahnya. Angel berpikir, seandainya ibunya tidak manja minta dijemput, tentunya kecelakaan itu tidak akan terjadi dan ayah Angel tidak akan meninggal dunia.

\section{Rasa salah}

Berikut ini adalah contoh kutipan data yang menunjukan adanya bentuk konflik batin yang terjadi pada tokoh utama berupa rasa salah yaitu sebagai berikut : "Aku melihatnya akan tetapi tidak memanggil dan berlalu begitu saja ke 


\section{RIA PERMATASARI \\ ANALISIS KONFLIK BATIN TOKOH UTAMA DALAM NOVEL IBU, AKU MENCINTAIMU KARYA AGNES DAVONAR}

kamarku. Ibu mungkin terlalu sibuk sampai tak sadar kepulanganku. Padahal ini sudah satu minggu kami tidak pernah bicara. Lama-lama, aku jadi berpikir mungkin aku juga salah telah membuat jarak antara kami" (2016"24).

Berdasarkan kutipan di atas, dapat diketahui bahwa bentuk konflik batin yang terjadi pada tokoh utama (Angel) yaitu bentuk konflik batin rasa salah. Bentuk konflik batin berupa rasa salah yang dialami oleh tokoh utama (Angel) dapat dibuktikan bahwa dalam kutipan tersebut Angel menyadari bahwa dia telah menciptakan jarak dengan ibunya setelah kematian ayahnya. Dan Angel merasa menyesal atas sikapnya yang telah menciptakan jarak

dengan ibunya

\section{Jengkel}

Bentuk konflik batin berupa jengkel dapat dilihat pada kutipan di bawah ini : "Aku melihatnya dengan jijik lalu Hendra mengajakku duduk dan menenangkan diri. Ia memintaku bersabar tapi aku merasa sangat terhina dengan kata-kata mereka" (Davonar, 2016:75)

Berdasarkan kutipan di atas, dapat diketahui bahwa bentuk konflik batin yang dialami oleh tokoh utama (Angel) adalah bentuk konflik batin jengkel. Bentuk konflik batin jengkel dapat dibuktikan bahwa dalam kutipan tersebut Angel merasa jijik dengan tingkah laku Agnes yang bersikap seenaknya. Angel merasa jengkel dengan sikap Agnes karena Agnes suka menghina Angel dan teman- temannya yang lain pun memilih untuk tidak meladeni atau mengalah dengan tingkah laku Agnes.

\section{Bimbang}

Bentuk konflik batin berupa bimbang yang dialami oleh tokoh (Angel) dapat dilihat pada kutipan di bawah ini:

"Hatiku merasa bingung, merasa kasihan akan tetapi juga malu bila orang-orang melihatku membantu ibu dan apa jadinya bila semua orang tahu kalau ibu pedagang bakmi ituadalah ibu

kandungku"(Davonar,2016:111).

Berdasakan kutipan di atas, dapat diketahui bahwa bentuk konflik batin yang dialami oleh tokoh utama (Angel) adalah bentuk konflik batin bimbang. Bentuk konflik batin bimbang yang dialami oleh tokoh utama (Angel) dapat dibuktikan bahwa dalam kutipan tersebut, Angel merasa bimbang untuk mengakui ibunya yang merupakan seorang penjual bakmi. Angel merasa kasihan kepada ibunya karena harus berjualan bakmi seorang diri tetapi jika Angel membantu ibunya berjualan bakmi, Angel akan malu jika orang lain mengetahui bahwa ibunya adalah penjual bakmi.

\section{Sakit hati}

Bentuk konflik batin berupa sakit hati yang dialami oleh tokoh utama (Angel) dapat dilihat pada kutipan di bawah ini:

"Terkadang aku merasa sakit hati ketika melihat Agnes dan Aji pulangsekolah dengan naik motor bersama bahkan makan dikantin pun mereka selalu bersama-sama" (Davonar,2016:154)

Berdasarkan kutipan di atas, dapat diketahui bahwa bentuk konflik batin yang dialami oleh tokoh utama (Angel) adalah bentuk konflik batin sakit hati. Bentuk konflik batin berupa sakit hati yang dialami oleh tokoh utama (Angel) dapat dibuktikan bahwa dalam kutipan tersebut Angel merasa sakit hati melihat kebersamaan Agnes dan Aji.

\section{Tidak Puas}

Bentuk konflik batin tidak puas dapat dilihat pada kutipan di bawah ini :

"Mungkin karena merasa aku mengeluh akhirnya suatu malam ia mengetukpintu kamarku dan memberikan aku sebuah hendphon. Aku mengambil dan memperhatikan merek hendphone itu yang awalnya ku piker iphone karena mirip. Ternyata setelah aku melihat mereknya rasanya gembiraku berubahitu buatan China yang hanya sekilas mirip iphone" (Davonar, 2015: 41).

Berdasarkan kutipan di atas dapat diketahui bahwa Angel mengalami bentuk konflik batin tidak puas. Angel merasa tidak senang dan tidak puas dengan hendphone pemberian ibunya. Angel mengira bahwa hendphone yang diberikan ibunya merupakan

merek iphone, tapi ternyata handphone yang diberikan ibunya merupakan handphone buatan China yang mirip dengan iphone. Sehingga Angel merasa tidak puas karena tidak memperoleh sesuatu yang diinginkannya.

\section{Ketergantungan}

Bentuk konflik batin berupa ketergantungan dapat dilihat pada kutipan dibawah ini : 


\section{RIA PERMATASARI \\ ANALISIS KONFLIK BATIN TOKOH UTAMA DALAM NOVEL IBU, AKU MENCINTAIMU KARYA AGNES DAVONAR}

"Hatiku hancur ketika sadar semua kebahagiaan yang ayah berikan selamaini dalam beberapa hari lagi akan lenyap tanpa alasan yang dapat aku terima selain semua karena ibu. Andai sajaayah tidak perlu menjemput ibu saat ia ada di salon, mungkin keluarga kamitidak akan sehancur ini. Ini semua karena ibu, aku benar-benar benci dan marah kepadanya" (Davonar, 2015:29).

Berdasarkan kutipan di atas dapat diketahui bahwa Angel mengalami bentuk konflik batin berupa ketergantungan. Angel mengalami bentuk konflik batin ketergantungan kepada ayahnya. Ketika ayahnya masih hidup Angel mendapatkan apa yang diinginkannya. Namun, setelah ayahnya meninggal kehidupan Angel menjadi berubah dan tidak bisa lagi mendapatkan apa yang diinginkannya.

Faktor Penyebab Konflik Batin Tokoh Utama dalam Novel Ibu, Aku Mencintaimu karya Agnes Davonar

\section{Persepsi Diri}

Faktor penyebab konflik batin berupa persepsi diri ditunjukan dalam kutipan berikut ini :

"...Andai saja ayah tidak perlu menjemput ibu saat ia ada di salon, mungkin keluarga kami tidak akan sehancur ini karena kemanjaan ibu, ini semua karena ibu. Aku benar-benar benci dan marah kepadanya. Aku benarbenar tidak ingin melihatnya lagi, apalagi harus sampai makan-makanan yang ia buat untukku, lebih baik aku mati kelaparan daripada harus makan" (Davonar, 2015:29)

Berdasarkan kutipan di atas, dapat dijelaskan bahwa Angel marah dan benci kepada ibunya karena akibat ibunyalah ayahnya meninggal. Seandainya ibunya tidak manja minta dijemput ayahnya ketika di salon, Angel berpikir bahwa ayahnya tidak akan mengalami kecelakaan dan meninggal dunia. Dan Angel tidak akan marah dan membenci ibunya.

Early Deprivation

Faktor penyebab konflik batin berupa Early Deprivation ditunjukan dalam kutipan di bawah ini :

"Untuk apa aku melakukan semua ini seandainya saja aku tidak semiskin ini, sungguh aku merindukan masa-masa bersama ayah dimana segala kebutuhanku tidak perlu diperjuangkan seberat ini apalagi sampai harus menguras otakku, tapi sekeras apapun aku berpikir untuk mengembalikan masa-masa indah itu rasanya mimpi pun akan sulit mengulanginya. Hidupku berjalan, dihadapanku kini adalah jalan yang harus kujalani termasuk siap menghadapi ibu yang mulai berjualan bakmi dalam beberapa hari lagi walau ia belum sadar" (Davonar, 2015:158)

Berdasarkan kutipan di atas, dapat dijelaskan bahwa Angel pasrah dalam menjalani kehidupan yang dirasakannya sangat sulit setelah kepergian ayahnya. Dalam hal ini mau tidak mau, senang tidak senang, Angel tidak bisa melakukan penolakan dalam menghadapi situasi yang dialaminya. Angel harus menjalani kehidupannya termasuk menerima kenyataan bahwa ibunya akan berjualan bakmi untuk kelangsungan hidupnya. Selain itu, Angel juga tidak dapat melanjutkan pendidikan ke sekolah yang diinginkannya

\section{Struktur Keluarga yang Patogenik}

Faktor yang menyebabkan konflik batin berupa struktur keluarga yang patogenik yang ditemukan dalam novel $I b u, A k u$ Mencintaimu karya Agnes Davonar dapat dilihat pada kutipan di bawah ini : "Ibu melihatku datang dan wajahku datar dengan penuh air mata. Kami sama-sama melihat tubuh dingin ayah yang sudah tak berdaya. Aku memeluk ayah dan menangis histeris. Aku hanya mencobamemanggilnya dan berharap ia bangun dari tidur panjangnya. Tetapi semua sia-sia, ayah tidak pernah bangun lagi. Ibu mencoba memelukku dari samping. Melihatnya aku jadi merasa bahwa semua kecelakaan ini karena ibu. Ibu yang memaksa ayah untuk menjemput, padahal ia memiliki supir pribadi, ia gengsi karena hanya dibawa oleh supir pribadi ke sebuah pesta seperti yang ia katakan padaku terakhir kali” (Davonar, 2016:17)

Berdasarkan kutipan di atas, dapat dijelaskan bahwa ayah Angel meninggal dalam kecelaaan sewaktu akan menjemput istrinya ke salon. Angel menjadi marah dan membenci ibunya karena telah menyebabkan ayahnya meninggal. Angel berpikir bahwa jika ibunya tidak manja dijemput di salon tentunya kecelakaan itu tidak akan terjadi dan ayahnya tidak akan meninggal. Sejak kematian ayahnya, 


\section{RIA PERMATASARI \\ ANALISIS KONFLIK BATIN TOKOH UTAMA DALAM NOVEL IBU, AKU MENCINTAIMU KARYA AGNES DAVONAR}

hubungan Angel dan ibunya menjadi renggang.

\section{SIMPULAN}

Berdasarkan hasil penelitian mengenai konflik batin tokoh utama pada novel Ibu, Aku Mencintaimu karya Agnes Davonar, peneliti dapat memberikan simpulan sebagai berikut :

Dalam novel Ibu, Aku Mencintaim karya Agnes Davonar, terdapat beberapa bentuk konflik batin yang dialami oleh tokoh diantaranya yaitu depresi, obsesi, cemas, marah, rasa salah, jengkel, sakit hati, bimbang, tidak puas, dan ketergantungan.

Dalam novel Ibu, Aku Mencintaimu karya Agnes terdapat faktor-faktor yang menyebabkan konflik batin yang terjadi pada tokoh utama yaitu persepsi diri, early deprivation, dan struktur keluarga yang patogenik.

\section{DAFTAR PUSTAKA}

Davonar, A. (2016). Ibu, $A k u$ Mencintaimu. Jakarta: PT. Inti Publisher.

Emzir dan Rohman. (2016). Teori dan Pengajaran Sastra. Jakarta: RajawaliPress.

Minderop, A. (2018). Psikologi Sastra. Karya, Metode, Teori, dan Contoh Kasus. Jakarta: Yayasan Obor.

Muis, S. (2009). Kenali Kepribadiaan Anda dan Permasalahannya dari Sudut Pandang Teori Psikoanalisa. Yogyakarta: Graha Ilmu.

Nurgiyantoro, B. (2018). Teori Pengkajian Fiksi. Yogyakarta: Gajah Mada UniversityPress.

Puspita, W. (2018). Manajemen Konflik (Suatu Pendekatan Psikologi, Komunikasi, dan Pendidikan). Yogyakarta: Deepublish.

Satinem. (2019). Apesiasi Prosa Fiksi: Teori, Metode, dan Penerapannya. Yogyakarta: Deepublish.

Siyoto, S., \& Sodik, M. A. (2015). Dasar Metodologi Penelitian. Yogyakarta:Pustaka Pelajar.
Wiramihardja. (2015). Pengantar Psikologi Abnormal. Bandung: PT Refika Aditama. 